\title{
Sustainable entrepreneurial ecosystems: an emerging field of research
}

Christine Volkmann, Klaus Fichter, Magnus Klofsten and David B. Audretsch

The self-archived postprint version of this journal article is available at Linköping University Institutional Repository (DiVA):

http:// urn.kb.se/ resolve?urn=urn:nbn:se:liu:diva-160109

N.B.: When citing this work, cite the original publication.

The original publication is available at www.springerlink.com:

Volkmann, C., Fichter, K., Klofsten, M., Audretsch, D. B., (2019), Sustainable entrepreneurial ecosystems: an emerging field of research, Small Business

Economics, , 1-9. https:// doi.org/ 10.1007/s11187-019-00253-7

Original publication available at:

https:// doi.org/ 10.1007/ s11187-019-00253-7

Copyright: Springer Verlag (Germany)

http:/ / www.springerlink.com/ ?MUD=MP 
Volkmann, C., Fichter, K., Klofsten, M. et al. Small Bus Econ (2019). https://doi.org/10.1007/s11187-

\title{
Sustainable entrepreneurial ecosystems: An emerging field of research
}

Christine Volkmann, Klaus Fichter, Magnus Klofsten and David B. Audretsch

Christine Volkmann, University of Wuppertal, Wuppertal, Germany

volkmann@wiwi.uni-wuppertal.de

ORCID (Christine Volkmann): 0000-0001-7355-5507

Klaus Fichter, Carl von Ossietzky University of Oldenburg, Oldenburg, Germany

Klaus.fichter@uni-oldenburg.de

ORCID (Klaus Fichter): 0000-0003-4392-3393

Magnus Klofsten, Linköping University, PIE/Helix Competence Centre, Linköping, Sweden

magnus.klofsten@liu.se

ORCID (Magnus Klofsten): 0000-0002-5960-9270

David B. Audretsch, Indiana University Bloomington, USA

ORCID (David B. Audretsch): 0000-0002-3815-7762

\begin{abstract}
While the concept of entrepreneurial ecosystems is now a prominent topic and an important stream in entrepreneurship research, the question how ecosystems can specifically promote sustainable entrepreneurship and contribute to the Sustainable Development Goals (SDGs) set by the United Nations is a neglected issue. With the papers in this special issue, we address this research gap, serving as a catalyst sparking more research at the nexus of contextualization of entrepreneurship and sustainability. This research has, since the 1990s, developed in three waves; the explicit linkage to SDGs and the investigation of impacts of entrepreneurship and entrepreneurial ecosystems in achieving societal and environmental goals might be considered as the "fourth wave." We first introduce relevant research streams and concepts for investigating sustainable entrepreneurial ecosystems. Then, we explain why
\end{abstract}


this special issue and its articles represent a fourth wave in entrepreneurial research ("sustainability"). Thereafter, we provide an overview of the papers of this special issue and then end with a brief consideration of future research demands.

\section{JEL classifications}

L26, M13, M14, O31, O32, Q01, Q55, Q56, R11

\section{Keywords}

Entrepreneurial ecosystems, sustainable entrepreneurship, sustainability, co-creation, coevolution, collective sustainable innovation

\section{Acknowledgments}

We thank Prof. Dr. Friederike Welter for her valuable comments on the draft of this paper.

\section{Ecosystems for sustainable entrepreneurship: Relevant research streams and concepts}

Entrepreneurship can contribute both to social welfare and to an "ecologically sustainable economy" (Dean \& McMullen, 2007, p. 69) and the view that economic development and environmental protection are a zero-sum game of social wealth has become outdated (Cohen \& Winn, 2007). In this sense, sustainable entrepreneurship is gaining prominence as entrepreneurs increasingly place sustainability next to profitability at the core of their business models.

\section{Sustainable entrepreneurship}

Within the entrepreneurship literature, sustainable entrepreneurship is an emerging research stream (Binder \& Belz, 2015; Demirel, Li, Rentocchini, \& Tamvada, 2019; Sarango-Lalangui, Santos, \& Hormiga, 2018). Sustainable entrepreneurship is defined as, "the discovery, creation, and exploitation of opportunities to create future goods and services that sustain the natural and/or communal environment and provide development gain for others" (Patzelt \& Shepherd, 2011, p. 632). These sustainable entrepreneurial activities are generally consistent with the UN's Sustainable Development Goals (Pacheco, Dean, \& Payne, 2010) and are, in turn, relevant for tackling fundamental societal challenges such as climate change, the provision of potable water for a growing world population, as well as the development of sustainable production and consumption patterns (United Nations General Assembly, 2015).

Sustainable entrepreneurship is considered to be an important contributor to the transition toward a sustainable economy (Hall, Daneke, \& Lenox, 2010). It encompasses entrepreneurial activity that embraces the economic, ecological, and social dimensions of sustainability as part 
of its core business model (Schaltegger \& Wagner, 2011). It can be concluded that, with regard to its intended and realized impact, sustainable entrepreneurship differs significantly from traditional entrepreneurship.

Past research stresses that entrepreneurial success depends on the support that entrepreneurs receive from other individuals (Hanlon \& Saunders, 2007). Despite the relevance of the external environment, with its stakeholder support for sustainable entrepreneurship, and an extant body of literature on "Entrepreneurship in Context" (Welter, Baker, \& Wirsching, 2019), there is a lack of research examining the contextual factors of sustainable entrepreneurship (Fichter et al., 2016). Such contextual factors might refer to specific legal, institutional, and regulatory frameworks (Ács, Autio, \& Szerb, 2014) as well as to historical, cultural, and socio-economic factors (Welter, 2011). In light of this, the question arises if there are any specific contextual factors that support or constrain sustainable entrepreneurship. Research on sustainable entrepreneurship suggests that the recognition and implementation of sustainable development opportunities are more complex for the entrepreneur than the recognition of non-sustainable opportunities (Patzelt \& Shepherd, 2011). Against this backdrop, it can be assumed that entrepreneurs creating, recognizing, and taking advantage of sustainable opportunities require specific relations and support for successful innovations and entrepreneurial activities within an ecosystem (Kanda, Hjelm, Clausen, \& Bienkowska, 2018). Therefore, it is critically important for societies and stakeholders to systematically facilitate the development of sustainable entrepreneurship (Cohen \& Winn, 2007; Schaltegger \& Wagner, 2011).

Presently, it is unclear if entrepreneurial ecosystems, as currently theorized in the extant literature and designed in practice, support sustainable entrepreneurship (see DiVito \& IngenHousz in this Special Issue). Sustainable entrepreneurs may require different ecosystems that provide support in significantly different ways than in traditional entrepreneurial ecosystems (Autio, Nambisan, Thomas, \& Wright, 2018; Neumeyer, Santos, Caetano, \& Kalbfleisch, 2018).

\section{Entrepreneurial ecosystems}

The concept of entrepreneurial ecosystems is increasingly popular idea (Audretsch \& Link, 2019; Spigel, 2017; Spigel \& Harrison, 2018). This is due to increasing interest from public, private, and civil society actors (Autio et al., 2018; Simatupang, Schwab, \& Lantu, 2015). Driven by national innovation policy to stimulate economic growth via entrepreneurial innovation, entrepreneurial ecosystems is gaining momentum in business theory and practice (Isenberg, 2011; Isenberg, 2010; Malecki, 2011; Spigel, 2017), motivating scholars to conceptualize entrepreneurship more holistically, as part of larger ecosystems with interactions between actors, such as institutions, firms, and individuals, engaging in innovative and entrepreneurial activity (Audretsch \& Belitski, 2017; Autio, Kenney, Mustar, Siegel, \& Wright, 2014).

An entrepreneurial ecosystem can be defined as "a dynamic community of inter-dependent actors (entrepreneurs, suppliers, buyer, government, etc.) and system-level institutional, 
informational and socioeconomic contexts" (Audretsch \& Belitski, 2017, p. 4). In this regard, different stakeholders, such as accelerator programs, incubators, business plan competitions, start-up awards, and public funding schemes, unfold synergies. Entrepreneurial ecosystems play an important role for the foundation and growth of enterprises (Isenberg, 2010) and determine the long-term prospects of regional development (Etzkowitz \& Klofsten, 2005; Simatupang et al., 2015) and sustainable urban development (Wirtz \& Volkmann, 2015).

Although scholars do not agree on a consistent, applicable definition of entrepreneurial ecosystems (Roundy, Bradshaw, \& Brockman, 2018; Stam, 2015), researchers share the collective vision of its systemic nature (see Pankov et al. 2019 in this Special Issue). Stam (2015, p. 5) emphasizes that, "the systemic conditions are the heart of the ecosystem." The systemic approach of ecosystems allows for a more comprehensive consideration of entrepreneurship by taking into account activities of several actors as well as their interrelation with a variety of contextual factors (Erina, Shatrevich, \& Gaile-Sarkane, 2017; Roundy et al., 2018). The growing interest in entrepreneurial ecosystems addresses the gap in the literature to understand entrepreneurial action (new value creation and capture) in complex, multi-level economic systems (Acs, Stam, Audretsch, \& O'Connor, 2017; Simatupang et al., 2015). How contextual factors influence the individual decision-making processes of entrepreneurs is a critical subtheme in the entrepreneurial ecosystem literature (Cohen, 2006; Neumeyer \& Santos, 2018).

There are two reasons why research on entrepreneurial ecosystems needs to be expanded and connected to sustainability research: First, the indifference of the sustainability dimension in the evolution of entrepreneurship practices leads to the presumption that ventures neglect their responsibility toward the environment and society (Daly \& Farley, 2010). Therefore, it is critically important for societies and stakeholders to systematically facilitate the development of sustainable entrepreneurship (Cohen \& Winn, 2007; Schaltegger \& Wagner, 2011). Second, the existing literature pays very little attention to the role of the sustainable entrepreneur in entrepreneurial ecosystems (Bischoff \& Volkmann, 2018; Fichter et al., 2016; Malecki, 2011). With regard to the insight that sustainable entrepreneurship requires distinct configurations of institutions and actors to thrive in entrepreneurial ecosystems, this is a clear deficit (Bischoff \& Volkmann, 2018; see also DiVito and Ingen-Housz in this special issue).

\section{Sustainable entrepreneurial ecosystems}

The notion of a sustainable entrepreneurial ecosystem (SEE) is a novel concept relating entrepreneurial ecosystems to sustainability issues and focusses on fostering sustainable entrepreneurship. Given the increasing pressure of fundamental societal challenges, such as climate change, the provision of potable water for a growing world population, and the development of sustainable production and consumption patterns (United Nations General Assembly, 2015), researchers began investigating the peculiarities of sustainable venture creation via perspective provided by the concept of sustainable entrepreneurial ecosystems. 
Until now, very few scholars directly focus on sustainability-related aspects of entrepreneurial ecosystems. In his paper, Cohen (2006) presents the example of a sustainable valley in Victoria, BC, Canada, where a cluster of innovative sustainable technologies was developed. According to Cohen (2006, p.3) a sustainable entrepreneurial ecosystem is, "an interconnected group of actors in a local geographic community committed to sustainable development through the support and facilitation of new sustainable ventures." Research suggests, for example, that the success of green start-ups depends on appropriate public and private support systems.

Uddin et al. (2015) examine the implementation of an SEE in the green IT sector and Simatupang et al. (2015) investigate the creation and development process of an SEE to support innovation and new business creation (see O'Shea et al. in this Special Issue). Studies explore the relationship between incubator programs and the creation of sustainable ventures (Bank, Fichter, \& Klofsten, 2017; Theodoraki, Messeghem, \& Rice, 2017), the interdependencies between business models and the development of sustainable ventures in entrepreneurial ecosystems (Muñoz \& Cohen, 2018; Neumeyer \& Santos, 2018), as well as several institutional constellations, such as regulatory policies, innovation climates, and social norms, that affect sustainable venture creation in geographic clusters (Sunny \& Shu, 2019). Bischoff and Volkmann (2018) highlight the necessity to merge the sustainable entrepreneurship literature with research on entrepreneurial ecosystems. In this regard, Bischoff (in this special issue) combines both research strands and empirically shows that certain contextual factors, such as engagement in sustainable venturing, matter particularly for SEEs. However, despite these initial conceptual and empirical investigations, research on the role of contextual factors in sustainable entrepreneurial ecosystems and their influence on sustainable activities of ventures is still in its infancy and many research questions remain unanswered (see Pankov et al. in this special issue). Furthermore, the few empirical investigations presently available reveal that specific support systems for sustainable entrepreneurship are still scarce in practice and, hence, can be considered as niche phenomena (Fichter et al., 2016). Such specific support systems and stakeholders as support actors are integral parts of sustainable entrepreneurial ecosystems.

\section{Sustainability: The fourth wave in entrepreneurship research}

The young research field on sustainable entrepreneurial ecosystems connects the scholarly examination of entrepreneurial ecosystems and sustainable entrepreneurship. This new field of research can be considered the next step in contextualizing entrepreneurship.

Entrepreneurial ecosystem issues, as well as sustainable entrepreneurship topics, are addressed in two special issues of Small Business Economics Journal. The special issue on "Born to be Green: Economics and Management of Green Start-ups" addresses relevant aspects from the nascent research field of green entrepreneurship, which can be considered an important sub-topic of sustainable entrepreneurship (Binder \& Belz, 2015, p. 53). It focuses 
on responses to environmental problems that demand immediate solutions (Demirel et al., 2019). The special issues on "Entrepreneurship in Context" and "The Governance of the Entrepreneurial Ecosystems" provide the latest research insights on the contextualization of entrepreneurship. In the introduction to these two special issues, Welter et al. (2019) outline three recent and overlapping waves of contextualization in the entrepreneurship field: "The discussion has moved from challenging the 'standard' or Silicon Valley model of entrepreneurship by considering the why, what, and how of entrepreneurship (first wave) towards considering more subjective elements and the construction and enactment of contexts (second wave), through challenging us to deepen our theorizing by broadening the domain of entrepreneurship research (third wave)" (Welter et al., 2019, p. 319).

In their outlook, Welter et al (2019) suggest that, while building on existing territory, new waves might arise. In this sense, we argue that entrepreneurial ecosystems, as a hot topic over the recent years (Brown and Mason, 2017), align with the notion of an "existing territory". Further, we argue that a potential fourth wave might be this movement toward a sustainable perspective in entrepreneurship research, moving beyond a pure economics basis. Hence, this fourth wave of entrepreneurship research might take larger societal and environmental contexts, as represented by the seminal global discourse on sustainable development (United Nations General Assembly, 2015), into account. ${ }^{1}$ Thus, the key difference between the third and fourth waves of entrepreneurship research is that the latter explicitly takes the larger societal and environmental contexts into account. Given the fact that sustainability research reflects a fundamental change in using and exploiting the natural environment, it seems justified to characterize sustainability-related entrepreneurship research as the fourth wave. Crutzen (2002) termed this new era the "Anthropocene." In his rationale, human activities are now significant geological forces, reshaping the globe through land use, deforestation and fossil fuel burning (Crutzen, 2006). This special issue on "Sustainable entrepreneurial ecosystems" and its articles are a first step toward this fourth wave of entrepreneurial research. Thereby, we also conform with the quest of Welter et al (2019) to consider the broad global challenges as new waves and to provide guidance in balancing the benefits and costs of sustainability-orientation for entrepreneurs and other stakeholders in entrepreneurial ecosystems.

We initiated a call for papers for a special issue on sustainable entrepreneurial ecosystems since this was the key topic at the 2017 G-Forum conference. ${ }^{2}$ Moreover, very few scholars have directly focused on sustainability-related aspects of entrepreneurial ecosystems. Research on ecosystems for sustainable entrepreneurship is still in its infancy and is missing

\footnotetext{
${ }^{1}$ The United Nations General Assemby (2015) outlines, for example, the societal and environmental relevance of intragenerational equality (e.g. issues of social injustice and stratification) and intergenerational equity (e.g. impacts of climate change on future generations),

${ }^{2}$ The G-Forum is one of the leading academic conferences exploring entrepreneurship in Europe. The conference is an initiative of the FGF (Förderkreis Gründungs-Forschung), which is the most significant scientific association for Entrepreneurship, Innovation and SME's in German-speaking countries.
} 
theoretical frameworks that specifically address the sustainability dimension. It also lacks empirical insights on how entrepreneurial ecosystems become sustainable and on the interrelation between contextual factors and sustainable entrepreneurship.

Against this backdrop, the purpose of this special issue is threefold:

(1.) to advance theoretical frameworks for investigating sustainable entrepreneurial ecosystems;

(2.) to gain evidence-based insights into the contextual factors of sustainable entrepreneurial ecosystems and their role in the development of sustainable ventures; and

(3.) to push and establish a research agenda on ecosystems and context factors for sustainable entrepreneurship.

\section{Contribution of the articles in this special issue}

This special issue chose five of the 24 submitted papers for publication; these five papers and their contributions are presented below. The aim of this special issue is to go beyond an economics analysis to provide a picture of sustainable entrepreneurial ecosystems. How each study contributes to this picture is summarized in Table 1.

DiVito and Ingen-Housz use a longitudinal single-case study of a collaborative innovation project in the denim industry to explore ways in which environmental, economic, and social needs are combined to create sustainable development while promoting social well-being. The study centers on a sustainable innovation project that has successfully transitioned from a general to a sustainable entrepreneurial ecosystem (SEE). It specifically focuses on the interactions among the entrepreneurial actors. The investigation builds on theoretical concepts that perceive sustainable entrepreneurship as an integrated, holistic perspective in pursuing opportunities embedded in entrepreneurial ecosystems. Entrepreneurial action is seen as taking place in complex, multi-level, economic systems. The empirical analysis reveals four factors that promote SEEs: the involved actors (i) have a sustainability orientation; (ii) recognize opportunities for sustainability and mobilizing resources; (iii) collaborate innovatively on ways to be sustainable; and (iv) find or create markets for their sustainable products. This case study illustrates the extreme interdependency and interactivity of entrepreneurial experimentation in the successful SEE. The study also recognizes that various actors in an SEE will participate in the discovery of sustainable opportunities and that in a sustainable entrepreneurial ecosystem, entrepreneurial experimentation is a highly interdependent and interactive process.

The paper by Pankov, Velamuri, and Schneckenberg focuses on the role of credibility and of sharing ventures in both evolving and sustaining a successful sustainable economy. Sharing, one possible pathway toward sustainable consumption patterns, is explored; the debate in the literature on sharing economies centers on the quality of their sustainability. This study is designed to explore the causes of the ambiguous activities carried out by some ventures. It 
builds on a theoretical framework for the contextual factors of sustainable entrepreneurial ecosystems. Thirty-seven interviews were conducted with upper management in sharing ventures. A comparative analysis reveals two groups of contextual factors that influence their sustainability orientation. The first group enforces behavioral rules and enables the development of organizational skills; these are considered positive. The second group, due to suppression of growth and market penetration, is considered restrictive. Thus, contextual factors can have an additive effect on the sustainable activities of shared ventures, giving rise to perceived ambiguity in some cases.

The focus of the O'Shea, Farny, and Hakala paper is the SEE and the co-evolution of entrepreneurial opportunities within the SEE. They apply a process perspective on ecosystems, introducing an evolving idiosyncratic view of entrepreneurial opportunities. They consider an SEE to be a learning system of co-evolving opportunities. The authors use a longitudinal study over three years, including interviews with pre-start-up teams within a nascent SEE in the field of high-tech cellulose based materials. Based on this data, the authors analyze how actors collaborate in the design and structuring phases of an ecosystem. The mutual support inherent in a well-functioning collaboration harmonizes the generation of ideas for new ventures and the opening up of new opportunities. The theoretical foundation that describes ecosystem processes and the SEE framework of the various phases of an emerging ecosystem during co-evolution are new and valuable contributions to the literature on entrepreneurial ecosystems, both general and sustainable.

One of the more important factors crucial to the success of new ventures is the surrounding entrepreneurial environment, defined as the network of local and regional stakeholders that support entrepreneurial aspirations and form a protective ecosystem. Bischoff explores a subset of this phenomenon in her quantitative analysis of entrepreneurial ecosystems that have a sustainable concept in Graz, Austria, and Wuppertal, Germany. She builds on stakeholder theory as well as concepts of sustainability and entrepreneurial culture. Following a literature review and the formation of a set of hypotheses, Bischoff identifies factors that influence the perception of successful SEEs: a regional culture supportive of entrepreneurism, stakeholder support specific for sustainable businesses, and collaborative networking fostering sustainable entrepreneurship.

In the final paper by Wagner, Schaltegger, Hansen, and Fichter, three German universities are analyzed in a comparative case study. The research design builds on the knowledge spillover theory of entrepreneurship, entrepreneurial ecosystem functions, and the theory of change. The latter provides a conceptual framework for investigating the outcomes and impacts of SEE. The paper explores current external strategic challenges that universities face - including partnerships, alliances, and stakeholders - to discover how public universities are faring in their new role of promoting development that is sustainable both regionally and economically. This societal role is over and above traditional mandates in teaching and research. Thus, universities currently choose to target SEEs by encouraging stakeholder participation on the regional level in regional governance processes as well as by encouraging knowledge spill- 
overs beneficial for regional development and revitalization. This comparative case study explores how support programs for sustainable entrepreneurship linked to universities affect sustainable development in the surrounding region. In this way, the interdependencies of the aforementioned external factors are analyzed, allowing for an investigation of the various roles of universities, of how knowledge spillovers occur, as well as of regional and national effects. Development of strong SEEs can be achieved with equal success along a variety of paths and configurations as well as with university involvement at various points, depending on the surrounding context. 
Table 1: Overview of articles in this special issue, "Sustainable entrepreneurial ecosystems"

\begin{tabular}{|c|c|}
\hline Authors & Contribution to the picture of sustainable entrepreneurial ecosystems \\
\hline DiVito and Ingen-Housz & $\begin{array}{l}\text { Contributes to our understanding of how entrepreneurial ecosystems become sustainable. Four aspects } \\
\text { foster sustainable entrepreneurial ecosystems: (i) sustainability orientation of actors; (ii) recognition of } \\
\text { sustainable opportunities and resources; (iii) collaborative innovation of sustainability opportunities; and } \\
\text { (iv) an existing market for sustainable products. }\end{array}$ \\
\hline $\begin{array}{l}\text { Pankov, } \\
\text { Velamuri, and Schneckenberg }\end{array}$ & $\begin{array}{l}\text { Demonstrates how contextual factors facilitate sustainable development within an entrepreneurial } \\
\text { ecosystem in the sharing economy. These are i) enforcement and adaption of behavioural rules and } \\
\text { development of organizational capabilities that foster sustainable activities in this specific ecosystem; } \\
\text { and ii) factors that impede the organizational agility of sharing ventures and hinder their growth restrict } \\
\text { the sustainable activities of sharing ventures. }\end{array}$ \\
\hline O’Shea, Farny, and Hakala & $\begin{array}{l}\text { Contributes to our understanding of the entrepreneurial process in a sustainable entrepreneurial } \\
\text { ecosystem, particularly the development of opportunities. The development of opportunities evolves in } \\
\text { three stages: co-intuiting, co-interpreting, and co-integrating. The development is enabled by an } \\
\text { emotional climate and a shared sustainability intention of the different actors. }\end{array}$ \\
\hline Bischoff & $\begin{array}{l}\text { Identifies factors that influence how different actors perceive the strength of specific sustainable } \\
\text { entrepreneurial ecosystems (Graz, Austria, and Wuppertal, Germany). In particular, the awareness of } \\
\text { entrepreneurship in combination with stakeholder support and collaboration matter for the positive } \\
\text { perception of a sustainable entrepreneurial ecosystem. }\end{array}$ \\
\hline Wagner, Schaltegger, Hansen, and Fichter & $\begin{array}{l}\text { Sheds light on how university-related support programmes, as one specific component of an } \\
\text { entrepreneurship ecosystem, foster sustainable regional development. Universities enable knowledge } \\
\text { spillovers that play a crucial role in a sustainable entrepreneurial ecosystem. }\end{array}$ \\
\hline
\end{tabular}


While this special issue advances our understanding of sustainable entrepreneurial ecosystems, the research field is only just emerging and we envision some promising avenues for the future development of the field.

Entrepreneurial ecosystems is an increasingly popular concept used by researchers to explain the formation and longevity of high-growth entrepreneurship across different regional clusters (Spigel, 2017; Brown \& Mason, 2017). However, fewer studies address how entrepreneurial ecosystems and sustainable entrepreneurial activities relate. The first direction for future research is to determine whether ecosystems that are successful in fostering traditional entrepreneurship also work in fostering sustainable entrepreneurial ecosystems. To what extent do archetype ecosystems, such as Silicon Valley, also benefit the formation of sustainable enterprises? Evidence suggests that the rates of traditional entrepreneurship correlate with the rates of social entrepreneurship on a country level (Lepoutre, Justo, Terjesen, \& Bosma, 2013). Are these findings also transferable to sustainable entrepreneurial activities? Accordingly, the question of how entrepreneurial ecosystems and sustainable entrepreneurial ecosystems interrelate is still open: are these overlapping concepts or complementary research fields? In concrete terms, a successful avenue for future research might be to investigate if the established components of entrepreneurial ecosystems, such as regional culture or capital markets, must be distinct for sustainable entrepreneurship. In this regard, future research might build on the concepts developed in the entrepreneurial ecosystem literature (e.g., Brown \& Mason, 2017; Audretsch \& Belitski, 2016). For example, with respect to entrepreneurial resource providers, the large pool of private investors is considered to be an essential part of an entrepreneurial ecosystem: onethird of US venture capital investments are made in Silicon Valley (Engel, 2015). In this regard, specific questions arise: is traditional venture capital also a premise for sustainable enterprises or do sustainable entrepreneurs primarily rely on "impact investors" (Bugg-Levine \& Emerson, 2011, Bergset \& Fichter, 2015)? Can new concepts, such as crowdfunding, foster sustainable entrepreneurial activities (Calic \& Mosakowski, 2016)?

Second, in line with the call of Acs et al. (2017) in a past special issue on entrepreneurial ecosystems, we seek to motivate future research that deepens our understanding of how to measure the performance of entrepreneurial ecosystems and their impact on the formation and longevity of sustainable enterprises. This kind of measurement constitutes a major challenge for research (Bruns, 2017). Studies discuss the presence and number of "unicorns" or "hidden champions" as an identifiable success measure for entrepreneurial ecosystems (e.g., Lehmann, Schenkenhofer, \& Wirsching, 2019) whilst taking into account regional boundaries (Stam, 2018). For sustainable entrepreneurial ecosystems, comparable indicators might neither be significant nor convincing. In this special issue, DiVito and Ingen-Housz, and Pankov et al. echo that the measures applied to assess the performance of entrepreneurial 
ecosystems, such as new firm creation and growth, might not capture the sustainability dimension of entrepreneurship. Thus, new metrics, such as the sustainable impact in terms of reduction in greenhouse gas emissions or the degree of empowerment, might complement economic indicators. Further, it would also be valuable to explicitly relate the outcomes and impacts of entrepreneurial ecosystems to the UN Sustainable Development Goals (2015). In this special issue, Bischoff proposes that the strength of an entrepreneurial ecosystem might be evaluated by using concrete outcome variables such as the number of established sustainable enterprises or the level of economic, environmental, and social value creation.

Third, future research might advance our understanding by exploiting different research methods, providing generalizable results for policymakers. The studies in this special issue mainly rely on case study and interview designs to identify and explore potential contextual factors that support sustainable entrepreneurial activities. This underpins the nascent state of research aspirations on sustainable entrepreneurial ecosystems. While the studies in this special issue deliver interesting new insights, the results can serve as a foundation for future quantitative studies. For example, future research might assess the long-term effects of specific contextual factors (see Wagner et al. in this Special Issue). Moreover, a fruitful avenue for future research might be to draw on quantitative data to compare ecosystems from different regions. Here the study of Bischoff comparing the ecosystems in Graz, Austria, and Wuppertal, Germany, in this special issue is an attempt. Despite the interesting insights, the study is restricted to two specific entrepreneurial ecosystems.

\section{Concluding Remarks}

Thus far, the contextualization of entrepreneurship has developed in three waves, with research focusing in particular on profit-driven entrepreneurs (Welter et al., 2019). In times of increased recognition of significant global challenges and threats like global warming and the wastage of non-renewable resources, this special issue aims to broaden contextual perspectives from a narrow focus on economic dimensions to the larger societal and ecological context. As sustainability is at the core of the agendas of national governments and the United Nations (United Nations General Assembly, 2015), entrepreneurship can significantly contribute to sustainable development and facilitate human wellbeing for current and future generations (Parrish, 2010). Accordingly, studies highlight the "important role of entrepreneurs in developing non-economic gains to society" (Shepherd \& Patzelt, 2011, p.141) and the crucial role of entrepreneurs as "catalysts to larger-scale socioeconomic structural transformations toward sustainability" (Parrish \& Foxon, 2009, p.47). This special issue aims to integrate sustainable entrepreneurship and entrepreneurial ecosystem research, noting that support from the entrepreneurial ecosystem is not only essential for entrepreneurial activities overall but sustainable entrepreneurship in particular (e.g., Bull \& Willard, 1993; Cohen, 2006; Gibbs, 2006; Hanlon \& Saunders, 2007). We believe the articles published in this special issue represent an expansion of contextual perspectives from a focus on economic dimensions to the larger societal and ecological context. They raise the 
awareness of a recent and fundamentally relevant topic, provide comprehensive insights on certain contextual factors that foster sustainable entrepreneurship, and, finally, point out potential areas for future research on the fourth wave of entrepreneurship research.

\section{References}

Ács, Z. J., Autio, E., \& Szerb, L. (2014). National Systems of Entrepreneurship: Measurement issues and policy implications. Research Policy, 43(3), 476-494. https://doi.org/10.1016/j.respol.2013.08.016

Acs, Z. J., Stam, E., Audretsch, D. B., \& O'Connor, A. (2017). The lineages of the entrepreneurial ecosystem approach. Small Business Economics, 49(1), 1-10. https://doi.org/10.1007/s11187-017-9864-8

Audretsch, D. B., \& Belitski, M. (2017). Entrepreneurial ecosystems in cities: establishing the framework conditions. The Journal of Technology Transfer. https://doi.org/10.1007/s10961-016-9473-8

Audretsch, D. B., \& Link, A. N. (2019). Embracing an entrepreneurial ecosystem: an analysis of the governance of research joint ventures. Small Business Economics, 52(2), 429-436. https://doi.org/10.1007/s11187-017-9953-8

Autio, E., Kenney, M., Mustar, P., Siegel, D., \& Wright, M. (2014). Entrepreneurial innovation: The importance of context. Research Policy, 43(7), 1097-1108. https://doi.org/10.1016/j.respol.2014.01.015

Autio, E., Nambisan, S., Thomas, L. D. W., \& Wright, M. (2018). Digital affordances, spatial affordances, and the genesis of entrepreneurial ecosystems: AUTIO ET AL. Strategic Entrepreneurship Journal, 12(1), 72-95. https://doi.org/10.1002/sej.1266

Bank, N., Fichter, K., \& Klofsten, M. (2017). Sustainability-profiled incubators and securing the inflow of tenants - The case of Green Garage Berlin. Journal of Cleaner Production, 157, 76-83. https://doi.org/10.1016/j.jclepro.2017.04.123

Bergset, L., \& Fichter, K. (2015). Green start-ups - a new typology for sustainable entrepreneurship and innovation research. Journal of Innovation Management, 3(3), 118-144.

Binder, J. K., \& Belz, F. M. (2015). Sustainable Entrepreneurship: What It Is. In P. Kyrö (Ed.), Handbook of Entrepreneurship and Sustainable Development Research (pp. 30-75). Retrieved from http://public.eblib.com/choice/PublicFullRecord.aspx?p=1934338

Bischoff, K., \& Volkmann, C. K. (2018). Stakeholder support for sustainable entrepreneurship - a framework of sustainable entrepreneurial ecosystems. International Journal of Entrepreneurial Venturing, 10(2), 172. https://doi.org/10.1504/IJEV.2018.092714 
Brown, R., \& Mason, C. (2017). Looking inside the spiky bits: a critical review and conceptualisation of entrepreneurial ecosystems. Small Business Economics, 49(1), 11-30.

Bruns, K., Bosma, N., Sanders, M., \& Schramm, M. (2017). Searching for the existence of entrepreneurial ecosystems: a regional cross-section growth regression approach. Small Business Economics, 49(1), 31-54.

Bugg-Levine, A., \& Emerson, J. (2011). Impact investing: Transforming how we make money while making a difference. Innovations: Technology, Governance, Globalization, 6(3), 9-18.

Bull, I., \& Willard, G. E. (1993). Toward a theory of entrepreneurship. Journal of business venturing, 8(3), 183-195.

Calic, G., \& Mosakowski, E. (2016). Kicking off social entrepreneurship: How a sustainability orientation influences crowdfunding success. Journal of Management Studies, 53(5), 738-767.

Cohen, B., \& Winn, M. (2007). Market imperfections, opportunity and sustainable entrepreneurship. Journal of Business Venturing, 22(1), 29-49.

Cohen, Boyd. (2006). Sustainable valley entrepreneurial ecosystems. Business Strategy and the Environment, 15(1), 1-14. https://doi.org/10.1002/bse.428

Crutzen, P. J. (2002). Geology of mankind. Nature, 415(6867), 23-23. https://doi.org/10.1038/415023a

Crutzen, P. J. (2006). The "Anthropocene." In E. Ehlers \& T. Krafft (Eds.), Earth System Science in the Anthropocene (pp. 13-18). https://doi.org/10.1007/3-540-26590-2_3

Daly, H. E., \& Farley, J. C. (2010). Ecological economics: principles and applications (2nd ed). Washington, DC: Island Press.

Dean, T. J., \& McMullen, J. S. (2007). Toward a theory of sustainable entrepreneurship: Reducing environmental degradation through entrepreneurial action. Journal of Business Venturing, 22(1), 50-76. https://doi.org/10.1016/j.jbusvent.2005.09.003

Demirel, P., Li, Q. C., Rentocchini, F., \& Tamvada, J. P. (2019). Born to be green: new insights into the economics and management of green entrepreneurship. Small Business Economics, 52(4), 759-771. https://doi.org/10.1007/s11187-017-9933-z

Engel, J. S. (2015). Global clusters of innovation: Lessons from Silicon Valley. California Management Review, 57(2), 36-65.

Erina, I., Shatrevich, V., \& Gaile-Sarkane, E. (2017). Impact of stakeholder groups on development of a regional entrepreneurial ecosystem. European Planning Studies, 25(5), 755-771. https://doi.org/10.1080/09654313.2017.1282077

Etzkowitz, H., \& Klofsten, M. (2005). The innovating region: toward a theory of knowledgebased regional development. $R \& D$ Management, $(35,3,2005), 243-255$. 
Fichter, K., Fuad-Luke, A., Hjelm, O., Klofsten, M., Backmann, M., Bergset, L., ... Kuisma, M. (2016). SHIFTing the Support of Entrepreneurship in Eco-Innovation. Summary of results and recommendations from the Eco-Innovera project SHIFT. Berlin, Helsinki, Linköping: SHIFT Consortium.

Gibbs, D. (2006). Sustainability entrepreneurs, ecopreneurs and the development of a sustainable economy. Greener Management International, 55, 63-78.

Hall, J. K., Daneke, G. A., \& Lenox, M. J. (2010). Sustainable development and entrepreneurship: Past contributions and future directions. Journal of Business Venturing, 25(5), 439-448. https://doi.org/10.1016/j.jbusvent.2010.01.002

Hanlon, D., \& Saunders, C. (2007). Marshaling Resources to Form Small New Ventures: Toward a More Holistic Understanding of Entrepreneurial Support. Entrepreneurship Theory and Practice, 31(4), 619-641. https://doi.org/10.1111/j.1540-6520.2007.00191.x

Isenberg, D. (2011). The entrepreneurship ecosystem strategy as a new paradigm for economic policy: principles for cultivating entrepreneurship. Dublin: Institute of International European Affairs.

Isenberg, D. J. (2010). How to start an entrepreneurial revolution. Harvard Business Review, $88(6), 40-50$.

Kanda, W., Hjelm, O., Clausen, J., \& Bienkowska, D. (2018). Roles of intermediaries in supporting eco-innovation. Journal of Cleaner Production, 205, 1006-1016. https://doi.org/10.1016/j.jclepro.2018.09.132

Lehmann, E. E., Schenkenhofer, J., \& Wirsching, K. (2019). Hidden champions and unicorns: a question of the context of human capital investment. Small Business Economics, 52(2), 359-374.

Lepoutre, J., Justo, R., Terjesen, S., \& Bosma, N. (2013). Designing a global standardized methodology for measuring social entrepreneurship activity: The Global Entrepreneurship Monitor social entrepreneurship study. Small Business Economics, 40(3), 693-714.

Malecki, E. J. (2011). Connecting local entrepreneurial ecosystems to global innovation networks: open innovation, double networks and knowledge integration. International Journal of Entrepreneurship and Innovation Management, 14(1), 36. https://doi.org/10.1504/IJEIM.2011.040821

Muñoz, P., \& Cohen, B. (2018). Sustainable Entrepreneurship Research: Taking Stock and looking ahead: Sustainable Entrepreneurship Research. Business Strategy and the Environment, 27(3), 300-322. https://doi.org/10.1002/bse.2000

Neumeyer, X., \& Santos, S. C. (2018). Sustainable business models, venture typologies, and entrepreneurial ecosystems: A social network perspective. Journal of Cleaner Production, 172, 4565-4579. https://doi.org/10.1016/j.jclepro.2017.08.216 
Neumeyer, X., Santos, S. C., Caetano, A., \& Kalbfleisch, P. (2018). Entrepreneurship ecosystems and women entrepreneurs: a social capital and network approach. Small Business Economics. https://doi.org/10.1007/s11187-018-9996-5

Pacheco, D. F., Dean, T. J., \& Payne, D. S. (2010). Escaping the green prison: entrepreneurship and the creation of opportunities for sustainable development. Journal of Business Venturing, 25(5), 464-480.

Parrish, B. D. (2010). Sustainability-driven entrepreneurship: Principles of organization design. Journal of Business Venturing, 25(5), 510-523.

Parrish, B. D., \& Foxon, T. J. (2009). Sustainability entrepreneurship and equitable transitions to a low-carbon economy. Greener Management International, 55, 47-62.

Patzelt, H., \& Shepherd, D. A. (2011). Recognizing Opportunities for Sustainable Development. Entrepreneurship Theory and Practice, 35(4), 631-652. https://doi.org/10.1111/j.1540-6520.2010.00386.x

Roundy, P. T., Bradshaw, M., \& Brockman, B. K. (2018). The emergence of entrepreneurial ecosystems: A complex adaptive systems approach. Journal of Business Research, 86, 1-10. https://doi.org/10.1016/j.jbusres.2018.01.032

Sarango-Lalangui, P., Santos, J., \& Hormiga, E. (2018). The Development of Sustainable Entrepreneurship Research Field. Sustainability, 10(6), 1-19. https://doi.org/10.3390/su10062005

Schaltegger, S., \& Wagner, M. (2011). Sustainable entrepreneurship and sustainability innovation: categories and interactions. Business Strategy and the Environment, 20(4), 222-237. https://doi.org/10.1002/bse.682

Simatupang, T. M., Schwab, A., \& Lantu, D. (2015). Introduction: Building Sustainable Entrepreneurship Ecosystems. SSRN Electronic Journal. https://doi.org/10.2139/ssrn.3161598

Spigel, B. (2017). The Relational Organization of Entrepreneurial Ecosystems. Entrepreneurship Theory and Practice, 41(1), 49-72. https://doi.org/10.1111/etap.12167

Spigel, B., \& Harrison, R. (2018). Toward a process theory of entrepreneurial ecosystems: Toward a process theory of entrepreneurial ecosystems. Strategic Entrepreneurship Journal, 12(1), 151-168. https://doi.org/10.1002/sej.1268

Stam, E. (2015). Entrepreneurial Ecosystems and Regional Policy: A Sympathetic Critique. European Planning Studies, 23(9), 1759-1769. https://doi.org/10.1080/09654313.2015.1061484

Stam, E. (2018). Measuring entrepreneurial ecosystems. In Entrepreneurial ecosystems (pp. 173-197). In: O'Connor, A., Stam, E., Sussan, F., Audretsch, D.B. (eds) Entrepreneurial Ecosystems. Place-Based Transformations and Transitions. New York: Springer 
Sunny, S. A., \& Shu, C. (2019). Investments, incentives, and innovation: geographical clustering dynamics as drivers of sustainable entrepreneurship. Small Business Economics, 52(4), 905-927. https://doi.org/10.1007/s11187-017-9941-z

Theodoraki, C., Messeghem, K., \& Rice, M. P. (2017). A social capital approach to the development of sustainable entrepreneurial ecosystems: an explorative study. Small Business Economics, 1-18. https://doi.org/10.1007/s11187-017-9924-0

Uddin, M., Hindu, R. C., Alsaqour, R., Shah, A., \& Saba, T. (2015). Knowledge management framework using green IT to implement sustainable entrepreneur ecosystem. Applied Mathematics \& Information Sciences, 9(5), 2703-2714.

United Nations General Assembly (Ed.). (2015). Transforming our world: the 2030 Agenda for Sustainable Development. Resolution adopted by the General Assembly on 25 September 2015. New York: United Nations.

Welter, F. (2011). Contextualizing Entrepreneurship-Conceptual Challenges and Ways Forward. Entrepreneurship Theory and Practice, 35(1), 165-184. https://doi.org/10.1111/j.1540-6520.2010.00427.x

Welter, F., Baker, T., \& Wirsching, K. (2019). Three waves and counting: the rising tide of contextualization in entrepreneurship research. Small Business Economics, 52(2), 319-330. https://doi.org/10.1007/s11187-018-0094-5

Wirtz, M., \& Volkmann, C. (2015). Social Entrepreneurial Ecosystems as a Means for Sustainable Urban Development. In J. Condy \& A. M. Cooper (Eds.), Dialogues of Sustainable Urbanisation (pp. 275-277). 